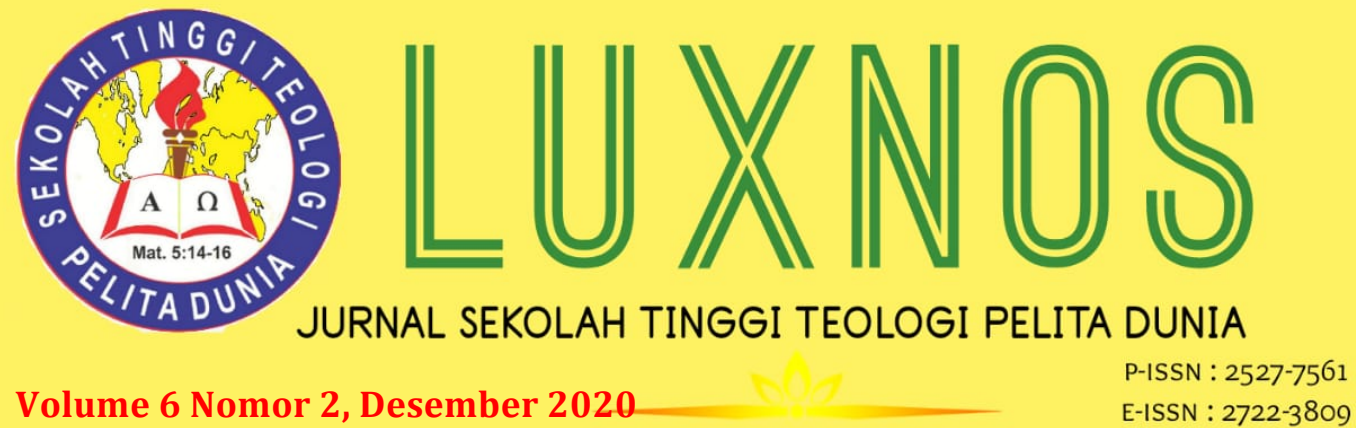

\title{
Karya Sosial Gereja: Studi Tentang GKI Cianjur
}

\section{Arthur Aritonang}

Sekolah Tinggi Teologi Cipanas

arthur.sttcipanas@yahoo.co.id

Abstract: An article entitled Church Social Work The Study of GKI Cianjur. This paper is raised by looking at the sociological facts that churches in Indonesia today display multi-faceted testimonies in the public sphere. So that the testimony of the churches in Indonesia is not the same in application. This is certainly confusing for non-Christian communities. There are various reasons why this can happen, among them: the legacy of zending theology that is still maintained by certain churches today, mentality (pessimistic attitude), unbalanced ministry orientation, paradigm that dichotomy church and world and charitative diaconia is carried out only at a time. certain. Therefore, this paper will present a theological reflection that strengthens the social responsibility of the Church. The method used in this research is qualitative methods and interview methods accompanied by documents in the form of photos of the results of services conducted by GKI Cianjur. As a conclusion from this research, with various examples of forms of service at GKI Cianjur, it can then be used as an example / model of social service for churches in Indonesia.

\section{Keywords: GKI Cianjur and society}

Abstrak: Artikel yang berjudul Karya Sosial Gereja: Studi Tentang GKI Cianjur. Tulisan ini diangkat dengan melihat fakta sosiologis bahwa gereja-gereja di Indonesia dewasa ini menampilkan kesaksian yang multi-wajah di ruang publik. Sehingga kesaksian gereja-gereja di Indonesia menjadi tidak sama dalam penerapannya. Hal ini tentu membingungkan bagi masyarakat yang bukan Kristen. Ada beragam faktor penyebab alasan mengapa hal demikian dapat terjadi diantarnya: warisan teologi zending yang masih dipertahankan oleh Gereja tertentu di masa kini, mentalitas (sikap pesimistik), orientasi pelayanan yang tidak seimbang, paradigma yang mendikotomi gereja dan dunia dan diakonia karitatif dilakukan hanya pada waktu tertentu. Oleh karena itu dalam tulisan ini akan disajikan refleksi teologis yang memperkuat tanggung jawab 
sosial Gereja. Metode yang digunakan dalam penelitian ini adalah metode kualitatif dan metode wawancara yang disertai dokumen berupa foto hasil pelayanan yang dilakukan oleh GKI Cianjur. Sebagai kesimpulan dari peneltian ini, dengan berbagai contoh bentuk pelayanan di GKI Cianjur kemudian bisa dijadikan contoh/model pelayanan sosial bagi Gereja-gereja di Indonesia.

Kata Kunci: GKI Cianjur, masyarakat

\section{Pendahuluan}

Dewasa ini gereja-gereja mengalami kondisi mentalitas yang cepat berpuas diri ketika para aktivis, majelis dan pendeta sudah menunaikan serangkaian kegiatan program pelayanan internal gereja dengan baik. ${ }^{1}$ Menurut penulis cara pandang demikian tidaklah salah, karena hal tersebut sangat baik demi pertumbuhan iman jemaat Tuhan. Namun, apakah Gereja dalam hal ini peka melihat tanda-tanda yang Tuhan berikan melalui fenomena sosial yang terjadi di sekitar Gereja? Apakah Gereja juga sudah sungguh-sungguh menangkap apa yang menjadi visi dan misi Allah untuk merepresentasikan keinginan dan harapan Allah bagi Gereja-Nya di tengah Dunia? Menurut Eben Timo, gereja sejatinya bukan hanya dimiliki oleh orang-orang Kristen saja, melainkan gereja adalah milik Tuhan dan manusia adalah tubuh-Nya. Manusia yang dimaksud adalah manusia Indonesia. Milik semua orang tanpa memandang SARA (Suku, Agama, Ras dan Antar Golongan).² Dengan kata lain, gereja disebut sebagai gereja ketika gereja terbuka bagi sesama dan bermanfaat bagi sesamanya yang membutuhkan. Menurut Binsar Nainggolan Keterlibatan sosial gereja bukanlah sebuah opsi, melainkan suatu bagian yang tidak terpisahkan dalam pelayanan gereja. Dalam Kitab Suci, jelas bahwa pelayanan sosial gereja berasal langsung dari Yesus Kristus (Mat. 25:35-36). Jika gereja sekarang ini melalaikan pelayanannya di lapangan sosial, maka warga jemaat maupun masyarakat akan menemukan gereja itu selaku institusi yang tidak relevan lagi. Fakta yang mengatakan bahwa gereja masih efektif dan berpengaruh dalam kehidupan masyarakat tentu akan diukur oleh realitas apakah gereja masih memiliki otoritas moral dalam membimbing umat ke arah jalan yang benar di lapangan sosial, ekonomi dan politik. ${ }^{3}$ Oleh karena itu, melalui artikel ini penulis akan berfokus pada pertanyaan tentang bagaimana GKI Cianjur dapat merealisasikan karya sosial di tengah masyarakat?

\section{Metode Penelitian}

\footnotetext{
${ }^{1}$ Wawancara, Einar M. Sitompul, 5 Juli 2018.

2 Ebenhaizer Nuban Timo, Meng-hari-ini-kan Injil di Bumi Pancasila Bergereja dengan Cita Rasa Indonesia (Jakarta: BPK Gunung Mulia, 2017), 42-44.

3 Binsar Nainggolan, "Keterlibatan Sosial Gereja dalam Pandangan Adolf von Harnack", Makalah Seminar, Ceramah dalam Rangka Dies Natalis STT Cipanas 2013, 7.
} 
Metode penelitan yang disajikan dalam artikel ini adalah metode kualitatif berdasarkan literatur buku yang menitikberatkan pada pembahasan mengenai tanggung jawab sosial gereja di tengah masyarakat. Menurut Adi Putra, "Semua kajian kualitatif di dalam penelitian ini bertumpu pada kajian literatur melalui sumbersumber primer seperti buku, artikel jurnal, ensiklopedia dan majalah". ${ }^{4}$ Selain itu, penulis juga melakukan kegiatan wawancara dengan Pendeta jemaat GKI Cianjur yaitu Hendra Setia Prasaja (melayani di GKI Cianjur sejak 2004-Mei 2019) dan dilengkapi dengan hasil bukti fisik berupa dokumentasi foto berkaitan dengan kegiatan pelayanan sosial yang selama ini dilakukan oleh GKI Cianjur kepada masyarakat sekitar.

\section{Pembahasan dan Hasil Penelitian}

\section{Pengaruh Pietisme Terhadap Cara Pandang Gereja Dalam Menyikapi Masalah Sosial}

Secara umum kekristenan di Indonesia merupakan sebuah deskripsi yang memperlihatkan minimnya kesadaran untuk menekankan kesatuan dalam tubuh Kristus, walaupun mempunyai identitas keyakinan yang sama. Berdasarkan fakta yang ada, fenomena ini terjadi karena setiap institusi gereja menjalankan aktifitas gerejawi sesuai dengan visi dan misi yang sudah ditetapkan oleh masing-masing Sinode Gereja dan juga dipengaruhi oleh corak teologi yang merupakan warisan dari badan zending. ${ }^{5}$ Perbedaan ini memberikan suatu gambaran bahwa gereja-gereja di Indonesia menampilkan wajah kekristenan yang berbeda-beda di ruang publik.

Menurut Gomar Gultom, gereja-gereja di Indonesia multi-wajah dalam menyingkapkan persoalan-persoalan yang ada di masyarakat. Wajah Pertama, gereja bersifat responsif dalam menyikapi persoalan yang dihadapi oleh masyarakat. Dengan demikian, gereja mencoba menjalankan peranannya sebagai garam dan terang di tengah bangsa melalui peran aktif gereja dalam megikuti kegiatan bermasyarakat dan berbangsa di dalam realitas sosial yang terjadi. Wajah Kedua, gereja menganggap bahwa persoalan yang terjadi di masyarakat merupakan persoalan masyarakat dan negara yang berwenang untuk mengurus hal tersebut. Dengan demikian, tugas gereja adalah beribadah, memuji Tuhan dan lain sebagainya. Hal ini mengakibatkan umat Kristen hanya hidup dalam tembok-tembok gereja dan dampaknya ialah gereja tidak bersentuhan antara hidup beribadah dengan hidup sosial. ${ }^{6}$ Pandangan ini terjadi karena gereja dipengaruhi oleh cara pandang yang dikotomis tentang dunia dan Surga. Implikasinya adalah persoalan yang terjadi di masyarakat kurang diperhatikan sebagai

4 Putra, Adi. "Kajian Biblika Terhadap Makna "Ta Stigmata Tou Iesou" dalam Galatia 6:

17." SUNDERMANN: Jurnal Ilmiah Teologi, Pendidikan, Sains, Humaniora Dan Kebudayaan 13.1 (2020): 1-

12.

5Wawancara, Dr. Einar M. Sitompul, 5 Juli 2018.

${ }^{6}$ Gomar Gultom, Peran Gereja Sebagai Garam dan Terang Dunia Bagi Bangsa Indonesia, https://www.youtube.com/watch?v=shs-phqh_s4, dipublikasikan 8 Desember 2017, diakses: 6 Juli 2018. 
tanggung jawab gereja. ${ }^{7}$ Wajah ketiga, menurut penulis adanya gereja tertentu yang memiliki pemahaman bahwa tugas pelayanan gereja di dalam menyikapi masalah sosial yang terjadi baik di masyarakat dan bangsa adalah hanya sebatas berdoa syafaat. Hal ini didasarkan bahwa persoalan yang terjadi di masyarakat sangat kompleks atau rumit, sehingga gereja dalam hal ini memiliki alasan khusus karena menyadari akan keterbatasannya. Dengan demikian, gereja menjadi pasif dan bersikap pesimis terhadap persoalan yang terjadi di masyarakat. Gereja hanya mempercayakan sepenuhnya persoalan-persoalan tersebut kepada Allah, dengan harapan Allah yang akan turun tangan untuk menyelesaikan setiap masalah dengan menggunakan lembaga atau institusi pemerintahan beserta segala perangkat yang dimilikinya tanpa melibatkan peran aktif dari gereja Tuhan di dalamnya. Wajah keempat, gereja hanya sekedar memberikan bantuan diakonia karitatif pada waktu-waktu tertentu kepada masyarakat yang ada di sekitar gereja, tanpa menyelidiki penyebab kemiskinan dan tanpa berpikir untuk mencari alternatif lain selain diakonia karitatif sebagai solusi untuk mengentaskan kemiskinan yang terjadi di masyarakat.

Pandangan di atas memperlihatkan adanya sebuah kaitan dengan pandangan dari Corinne Ware dalam bukunya Discover Your Spiritual Type. Menurut Corrine Ware, ada empat corak pengalaman spiritualitas gereja dalam hal ini yang dimaksudkan ialah orang-orang yang berhimpun dalam persekutuan di gereja, yaitu: Speculative/Kataphatic - A Head Spirituality; Spiritualitas intelektual. Seseorang dengan corak spiritual seperti ini akan menghubungkan dirinya dengan Tuhan melalui meneliti, mempelajari Kitab Suci (belajar teologia) dan merenungkan kata-kata-Nya di dalam Kitab Suci sehingga memiliki pemahaman atau konsep tertentu. (2) Affective/Kataphatic - A Heart Spirituality; Spiritualitas Hati. Seseorang dengan corak spiritual seperti ini akan berelasi dengan Allah melalui ibadah, musik dan doa. Secara teologis, pengalaman ini menekankan imanensi Tuhan atas transendensi Tuhan. (3) Affective/Apophatic - A Mystic Spirituality; Spiritualitas Mistis. Seseorang dengan corak spiritual seperti ini akan berupaya untuk mendekati Allah dengan cara menyepi, mengasingkan diri (asketisme) dan melakukan tindakan-tindakan kontemplasi. Tujuan dari spiritualitas ini adalah untuk mencapai kesucian hidup (Pietisme). Orang-orang ini dipandang sebagai orang yang anti-intelektual dan eksklusif. (4) Speculative/Apophatic - A Kingdom Spirituality; Spiritualitas Kerajaan. Orang dengan tipe spiritual seperti ini [pada umumnya dikenal sebagai seorang aktivis] kurang peduli tentang afiliasi dengan agama yang terorganisir. Tipe ini memiliki hasrat dan tanggung jawab yang kokoh tentang bagaimana memperjuangkan terwujudnya Kerajaan Allah di bumi, sebagaimana dahulu

\footnotetext{
${ }^{7}$ Agustinus Purba, gereja dan kemiskinan, dalam "Ngapain Peduli yang lain! Gereja agen perubahan di tengah budaya masyarakat majemuk dan global-Refleksi Emeritasi Pdt. Nelson Flores Siregar", ed. Jhon Kristo Naibaho dan Morrys Syahputra Marpaung, (Siborong-borong: Lembaga Bina Warga HKBP, 2017), 57.
} 
diperjuangkan oleh nabi-nabi Ibrani dan para bapa gereja seperti Martin Luther dan John Calvin. ${ }^{8}$

Menanggapi hasil penelitian dari Corinne Ware, Robby I. Chandra (Ketua komisi pembinaan para pendeta di sinode GKI wilayah Jawa Barat) mendapatkan suatu kesimpulan bahwa setiap kesaksian dari gereja yang multi-wajah yang diperlihatkan di ruang publik sangat dipengaruhi oleh bagaimana sikap seseorang dalam menanggapi atau meresponi akan anugerah penyataan Allah sehingga terbentuk empat corak pengalaman spiritualitas gereja. Di sisi lain, ia juga berpendapat bahwa setiap orang yang meresponi akan anugerah Allah harus ditandai dengan adanya perubahan yang terjadi dalam kehidupan pribadinya dan kehidupan sosialnya kepada sesama. ${ }^{9}$ Untuk memperkuat pandangan Robby Chandra, maka Aritonang dalam bukunya Mereka Juga Citra Allah Hakikat dan Sejarah Diakonia ..., berpendapat bahwa sikap dan aksi kepedulian dengan sesama atas kehidupan sosialnya harus didorong oleh iman dan rasa syukur kepada Tuhan. Dengan demikian, para pelaku diakonia sekaligus diingatkan untuk menguji motivasi mereka: apakah semua itu sungguh merupakan ungkapan iman dan rasa syukur kepada Tuhan untuk menolong sesama yang dilayani atau sebaliknya untuk memuaskan diri dan ambisi para pelaku. ${ }^{10}$

Berdasarkan pandangan di atas, tentunya cara pandang gereja dalam menyikapi masalah sosial yang terjadi di sekitar gereja sangat dipengaruhi oleh corak pengalaman spiritualitas masing-masing anggota jemaat antara satu sama lain yang sangat berbeda. Menurut penulis, corak pengalaman spiritualitas ini memiliki kekuatan dan kekurangan atau kelemahannya masing-masing. Meskipun demikian, seharusnya pengalaman spiritualitas anggota jemaat menjadi penggerak bagi setiap anggota gereja untuk memiliki indikator yang sama yakni bagi kemanusiaan artinya hidup yang berjuang untuk mengangkat harkat dan martabat sesama yang selama ini terabaikan dan tidak mampu bersuara atas penderitaan hidup yang dialami oleh mereka.

Berkaitan dengan hal tersebut, tidak dapat disangkal bahwa sejarah gereja mencatat gereja di Indonesia juga dipengaruhi oleh Badan-badan Pekabaran Injil yang diwarnai oleh semangat Pietisme dan kesalehan yang ada dalam Pietisme. Oleh sebab itu, corak Pietisme menekankan kesalehan dan hubungan vertikal dengan Tuhan tetapi mengabaikan dunia yang dipraktikkan dan diajarkan oleh tokoh-tokoh zending. Itulah

8Discover Your Spiritual Type: A guide to Individual and Congregational Growth Extracts from the Alban Institute Publication by Corinne Ware. 1995, dalam http://youthministry.org.nz/wpcontent/dox/groundwork_faith/personalspirituality.pdf, diakses: diakses: 9 Juli 2018.

${ }^{9}$ Wawancara, Robby I Chandra, 11 Juli 2018.

10Jan Sihar Aritonang, Mereka Juga Citra Allah Hakikat dan Sejarah Diakonia Termasuk bagi Yang Berkeadaan dan Berkebutuhan Khusus (Buruh, Migran \& Pengungsi Penyandang Disabilitas, LGBT), (Jakarta: BPK Gunung Mulia, 2017), 13. 
sebabnya sikap merendahkan dunia (masyarakat) yang menjadi salah satu keunikan Pietisme kadang-kadang terlihat dalam kehidupan gereja-gereja di Indonesia. ${ }^{11}$

Sikap Pietisme tercermin dari teks nyanyian jemaat dari kaum Pietistis yang memberi kesan kuat akan adanya negasi (penolakan) terhadap peranan sosial orang percaya dalam penataan kehidupan bermasyarakat menjadi lebih baik. Hal ini merupakan sebuah tindakan yang menyimpang dari kesaksian Alkitab. Teks nyanyian kalangan Injili lebih merupakan sebuah ungkapan kesalehan yang subjektif, emosional dan tanpa harga sosial politik. Hidup beriman direduksi menjadi hanya sekadar soal asuransi keselamatan pribadi dari api neraka. Dalam teks lagu-lagu tersebut, iman dipahami sebagai sebuah slogan rohani sedangkan tanggung jawab sosial dan politik untuk memperbaiki kehidupan politik, membongkar struktur sosial yang menindas, menolong "the nobodies" dan memiliki harkat dan martabat sebagai the somebodies, tidak termasuk dalam perbendaharaan iman. ${ }^{12}$ Di kalangan gereja-gereja arus utama, nyanyian-nyanyian jemaat justru tidak terjerumus dalam kencenderungan ini. Lagulagu dalam Kidung Jemaat; Nyanyikanlah Kidung Baru; Pelengkap Kidung Jemaat memiliki konsekuensi sosial yang jelas dan orang percaya bahwa melalui teks-teks lagu tersebut, setiap orang dipanggil untuk ikut bekerja bagi pembaharuan masyarakat ke arah keadilan dan kesejahteraan bersama. ${ }^{13}$

Dengan demikian, sudah waktunya gereja meninggalkan (nyanyian Pietisme), warisan pemikiran zending yang dipengaruhi oleh filsafat Yunani (Gnostik) dan faktor sejarah yang dialami oleh negara Jerman akibat perang selama 30 tahun (1618-1648) yang sangat memprihatinkan. Budaya manusia hancur, dekadensi (kemerosotan) moral, kekerasan terjadi di mana-mana. Oleh sebab itu, Pietisme menjadi jalan terbaik untuk menjauhkan diri dari dunia. ${ }^{14}$ Sikap menjauhkan diri dari dunia ini ketika itu masih

${ }^{11}$ Leonard Hale, Jujur terhadap Pietisme: Menilai Kembali Reputasi Pietisme dalam Gereja-Gereja di Indonesia (Jakarta: BPK Gunung Mulia, 1993), 5.

Pietisme merupakan suatu gerakan keagamaan yang menekankan pentingnya kesalehan hidup, ketaatan terhadap Alkitab, pertobatan, dan semangat penginjilan. Gerakan ini berlangsung antara akhir abad XVII hingga pertengahan abad XVIII sebagai reaksi terhadap kondisi gereja di kalangan Lutheran yang ritual-ritualnya dipandang sangat formal dan mekanis. Istilah Pietisme pertama kali muncul dan populer di kalangan gereja Lutheran sekitar tahun 1677. Istilah ini ditujukan pertama kali pada sekelompok jemaat Lutheran yang hidup saleh (Collegia Peitatis). Dan bila kita menelaah latar belakang munculnya kelompok ini menurut penuturan Leonard Hale, maka kehadiran Collegia Peitatis merupakan suatu upaya melakukan reformasi dalam jemaat dan masyarakat, khususnya di wilayah Jerman (Baca: Rudy Harold, "Peran "Teologi Sosial" Gereja Protestan Indonesia di Gorontalo (GPIG) dalam Menanggapi Masalah Kemiskinan, Jurnal Jaffray, Vol. 15, No. 1, April 2017, 131-147)

12 Ebenhaizer Nuban Timo, ... 343-344.

13 Ibid, ... 344 .

${ }^{14}$ Leonard Hale, Diutus ke Dalam Dunia Menyelisik Teologi Abineno dan Kontribusinya bagi Gereja-gereja di Indonesia, (Jakarta: BPK Gunung Mulia, 2016), 71-74. Penjelasan tentang "Gnostik" ialah aliran sinkretis yang mengatakan bahwa Dunia tidak dilihat sebagai ciptaan Allah yang baik, tetapi dunia bersifat materi yang penuh ketidakpastian, sumber segala yang jahat. Lewat askese manusia berusaha keras menjaga kemurnian jiwa agar tidak terkontaminasi, sebab manusia menjadi rusak karena tercengkeram dalam dunia materi (Bnd. Th. Van den End, Harta Dalam Bejana (Jakarta: BPK Gunung Mulia, 1997), 34-39. 
terus berlangsung pada abad selanjutnya ketika memasuki abad ke-17 dan 18, yang kemudian disusul dengan revolusi industri pada abad ke-19 waktu itu banyak gereja berprilaku seperti menara gading (ivour tower) yang hanya melihat umat dari puncak menara gading itu tanpa mau terjun melibatkan diri dalam permasalahanpermasalahan sosial. Akibatnya sejumlah orang semakin tidak merasakan arti kehadiran gereja dalam hidupnya. ${ }^{15}$

Bagaiman dengan di Indonesia? sejak Sidang Raya Dewan gereja-gereja di Indonesia (DGI/PGI) tahun 1971 di Pemantang Siantar gereja-gereja berusaha untuk meninggalkan pemahaman Injil yang sempit dan berusaha berteologi dengan lebih terbuka terhadap masalah sosial. ${ }^{16}$ Namun meskipun demikian faktnya masih ada warisan pietisme yang dipertahankan oleh gereja-gereja di Indonesia yang menekankan usaha-usaha memenangkan jiwa untuk Kristus membangun jemaat-jemaat, kesalehan pribadi dan keselamatan jiwa. ${ }^{17}$ Bagi penulis pandangan tersebut harus diperluas bukan hanya sekadar menaruh perhatiannya terhadap keselamatan dimasa mendatang (Surga) tetapi situasi dan kondisi dewasa ini yang disebabkan oleh karena proses moderenisasi yang sedang berlangsung pesat dihampir semua negara di dunia ini sehingga berakibat terjadinya persaingan global yang juga dirasakan oleh masyarakat Indonesia secara khusus di kab Cianjur sehingga memiliki impact sosial salah satunya kesenjangan sosial yang kaya semakin kaya dan yang miskin semakin miskin. Oleh karenanya, menurut Eben Timo dalam hal ini gereja harus mendorong jemaatnya untuk mengakomodasi kenyataan-kenyataan sosial kemasyarakatan sebagai jalan untuk terjadinya transformasi publik. ${ }^{18}$ Upaya transformasi publik saat ini sedang dilakukan oleh GKI Cianjur. GKI Cianjur terus berupaya untuk mewujudnyatakan visi Sinode am GKI yaitu menjadi mitra Allah dalam menghadirkan damai sejahtera di dunia (dalam hal ini ialah: masyarakat kabupaten kota Cianjur).

\section{GKI Cianjur dan Karya Sosial}

Pada bagian ini, penulis akan memberikan gambaran dan program pelayanan sosial GKI Cianjur yang berlokasi di Jl. HOS Cokrominoto No. 55, Muka, Kecamatan Cianjur, Kabupaten Cianjur, Jawa Barat. Namun sebelumnya penulis akan memberikan gambaran data statistik tahun 2017 mengenai jumlah kemiskinan di Kabupaten Cianjur.

Menurut Sapturo (Wakil Ketua Komisi IV DPRD Kabupaten Cianjur), setelah menerima laporan data KIS (Kartu Indonesia Sehat) dari Dinas Sosial Kabupaten

\footnotetext{
15 Binsar Nainggolan, "Keterlibatan Sosial Gereja dalam Pandangan Adolf von Harnack”, Makalah Seminar, dalam Rangka Dies Natalis STT Cipanas ke-46 tahun 2013, 6-7.

${ }^{16}$ Andreas A. Yewangoe, Theologia Crucis Di Asia Pandangan-Pandangan Orang Kristen Asia mengenai Penderitaan dalam Kemiskinan Dan Keberagamaan di Asia (Jakarta: BPK Gunung Mulia, 1996), 271-277.

17 Ibid., 277-280

18 Ebenhaizer Nuban Timo, ... 155.
} 
Cianjur, menyebutkan bahwa ada sekitar satu juta penerima KIS di Cianjur, ditambah dengan 51 ribu warga yang terdaftar di Jamkesda (Jaminan Kesehatan Daerah). "Dibandingkan dengan jumlah penerima KIS dan Jamkesda, ada sekitar 1,051,000 jiwa sementara jumlah penduduk Cianjur sekitar 2,3 juta jiwa. Dengan demikian, hampir 50 persen penduduk Cianjur termasuk dalam kategori miskin," ucapnya saat ditemui di Kantor DPRD Kabupaten Cianjur, kemarin (24/7). Selain itu Sapturo juga menambahkan bahwa Pemerintahan Kabupaten Cianjur sedang melakukan upaya peningkatan kesejahteraan, seperti pemberian bantuan modal bagi yang masih mampu bekerja dan bantuan untuk kebutuhan sehari-hari bagi yang jompo dan sudah tidak mampu lagi bekerja. ${ }^{19}$

Melihat akan kondisi bahwa 50 persen masyarakat Cianjur dinyatakan miskin, GKI Cianjur memiliki kesadaran untuk menjadikan gereja sebagai sahabat bagi masyarakat bahkan berupaya sebisa mungkin menjadi solusi bagi masyarakat. Namun sebelumnya ada proses yang perlu dilakukan mengenai bagaimana cara menggerakan warga jemaat GKI Cianjur agar memiliki kesadaran yang sama. Maka dalam kaitan ini sebagai pendeta jemaat, Pdt. Hendra perlu melakukan penelitian lapangan agar mendapatkan sebuah data dan fakta yang akurat untuk disampaikan kepada para majelis dan warga jemaat. Oleh karena itu, melalui data tersebut majelis jemaat GKI Cianjur memberikan respons yang positif sehingga kegiatan aksi peduli masyarakat bisa terealisasi. ${ }^{20}$

Menjawab akan persoalan yang terjadi di sekitar masyarakat Cianjur, GKI Cianjur membentuk tim relawan pelayanan kepada masyarakat yang dinamakan S3 (Sangu Setiap Sabtu). Kegiatan ini merupakan aksi sosial lintas agama dalam bentuk perhatian kepada orang-orang yang kurang mampu dan termarjinalkan yang dilaksanakan setiap Sabtu pukul 20:00-22:00 WIB. Waktu pelaksanaannya terkadang bisa berubah sesuai dengan situasi dan kondisi. GKI Cianjur menyadari bahwa dari segi keuangan gereja tidak besar dan mengingat dari segi luasnya ruang lingkup pelayanan sosial, GKI Cianjur menyadari bahwa pelayanan sosial tidak bisa ditunaikan hanya oleh GKI Cianjur secara sepihak. Oleh karena itu, GKI Cianjur mengajak dan sekaligus mensosialisasikan agenda pelayanan sosial bagi gereja-gereja di sekitar Kabupaten Cianjur untuk bergandengan tangan dalam melakukan aksi peduli masyarakat. ${ }^{21}$

Pelayanan diakonia (sosial) terdiri dari tiga kategori yang harus dijalankan, yaitu: (1) Karitatif (berdasarkan belas kasihan dan kemurahan hati). Contohnya: memberi bantuan material dan merawat yatim-piatu, janda dan jompo. (2) Reformatif (mengupayakan pembaharuan masyarakat). Conohnya: melalui pendidikan, pelatihan

19 Setengah penduduk di Kabupaten Cianjur dinyatakan miskin dalam http://jabarekspres.com/2017/setengah-pen\%C2\%ADduduk-kabupaten-cianjur-dinyatakan-miskin/, diakses: 9 Juli 2018

20 Wawancara, Pdt. Hendra SP., oleh penulis 11 Juli 2018.

21 Ibid. 
dan kesehatan. (3) Struktural-transformatif (menggali dan membongkar penyebab masalah dan menata struktur kehidupan). Contohnya: melalui sikap protes terhadap sistem kekuasaan, perbaikan perundang-undangan, pendampingan atau advokasi dan penyadaran. ${ }^{22}$

Sehubungan dengan itu, penulis akan memperlihatkan bentuk kegiatan pelayanan yang rutin dilakukan sampai dengan saat ini dan program yang sedang direncanakan di waktu mendatang agar dapat direalisasikan oleh GKI Cianjur yang berkerjasama dengan berbagai pihak termasuk juga berbagai institusi beserta para donatur di dalamnya, sehingga pada ahirnya segala kegiatan pelayanan akan bermanfaat bagi masyarakat. Berikut ini adalah kegiatan yang dilakukan oleh GKI Cianjur:

(1) GKI Cianjur pernah mengadakan pasar murah yang diadakan di halaman Gereja, yang dialamatkan kepada masyarakat Cianjur yang berasal dari ekonomi menengah ke bawah.
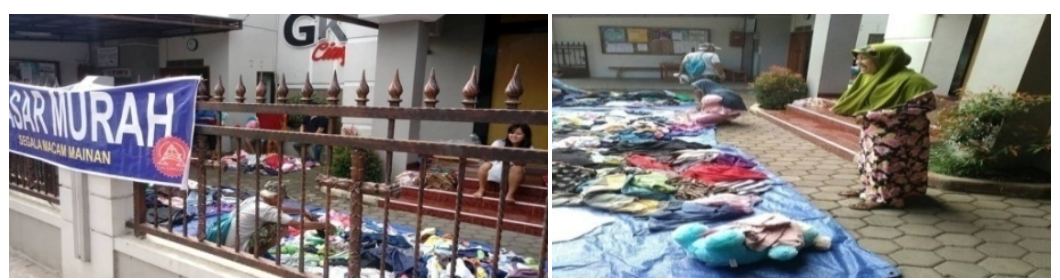

(2) GKI Cianjur juga memberikan jasa pelayanan mobil ambulance bagi jenazah dan orang sakit secara gratis bagi warga masyarakat Cianjur yang membutuhkannya untuk segera diantarkan ke RS (Rumah Sakit) yang ingin dituju seperti Rumah Sakit yang berada di sekitar Kabupaten Cianjur ataupun Bandung. Pelayanan seperti ini sudah banyak membantu warga sekitar.
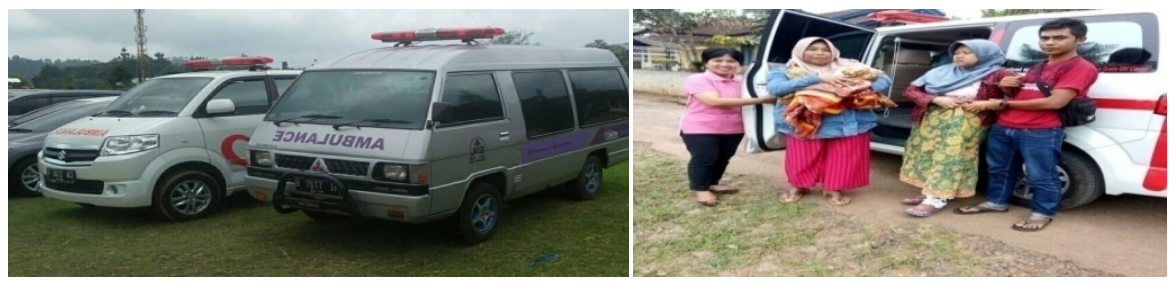

(3) Tim relawan S3 juga memperjuangkan para tunawisma yang ada di sekitar daerah Cianjur untuk memperoleh KTP agar identitasnya dapat dikenali dan sah secara hukum.

22 Jan Sihar Aritonang dan Asteria T. Aritonang, Hakikat dan Sejarah Diakonia Termasuk bagi yang Berkeadaan dan Berkebutuhan Khusus (Buruh, Migran \& Pengungsi Penyandang Disabilitas, LGBT), 21. 


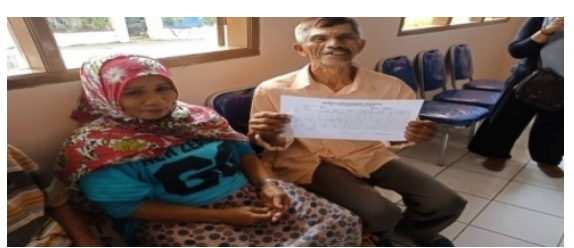

(4) Pada 31 Mei 2018 GKI Cianjur sedang merencanakan pembangunan rumah singgah bagi pasien yang tidak mampu. Pembangunan rumah singgah tersebut berlokasi dekat Rumah Sakit Sayang Kabupaten Cianjur, dengan harapan kehadiran rumah singgah ini banyak yang akan tertolong. Upaya yang sedang dilakukan oleh GKI Cianjur yaitu mengumpulkan dana dengan cara menggunakan undangan terbuka secara personal maupun institusi. Selain itu, S3 juga mempunyai program peduli sesama dengan cara mengundang warga gereja atau yang bukan warga gereja untuk dengan senang hati memberikan sumbangan beras dan kemudian beras yang sudah terkumpul akan dialokasikan kepada masyarakat sekitar yang tidak mampu.
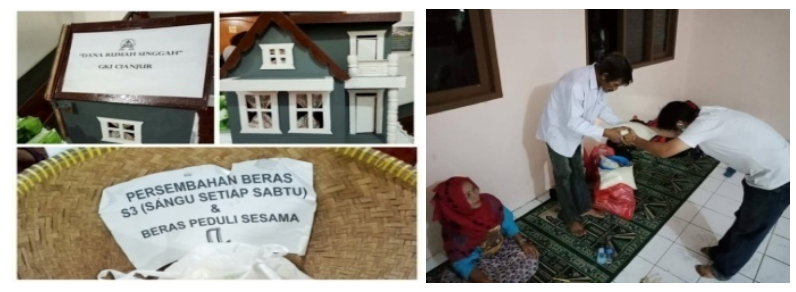

(5) Tim S3 juga melakukan pelayanan kepada orang-orang yang mengalami gangguan kejiwaan yang seringkali diabaikan dan tersisihkan dari lingkungan masyarakat. Tim S3 melakukan pendekatan kepada orang-orang yang mengalami gangguan kejiwaan yang nantinya akan dibawa ke panti rehab KSJ (Komunitas Sehat Jiwa).

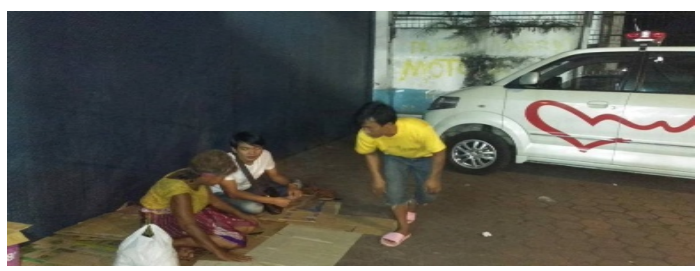

(6) GKI Cianjur bekerjasama dengan masyarakat dan gereja-gereja di sekitar Kabupaten Cianjur untuk mendirikan sebuah rumah belajar.

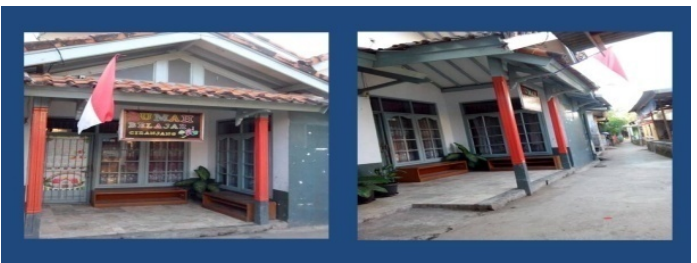


(7) Tim S3 juga memiliki program pemberian dana kredit usaha rumah tangga kepada rakyat yang kurang mampu dalam melakukan usaha pekerjaan.

(8) Melakukan diakonia transformatif. Menurut Pdt. Hendra, diakonia transformatif ini pernah berhasil dilakukan di tahun 2008 yang pernah digagas oleh pihak GKI Cianjur yang bekerjasama dengan Lembaga P3M (Pusat Pengembangan Pesantren dan Masyarakat) untuk mendesak pemerintah daerah dalam hal menambahkan anggaran kesehatan di daerah Kabupaten Cianjur dengan cara membangun sebuah rumah sakit karena pada saat itu hanya ada 1 rumah sakit di Cianjur yaitu RSUD Cianjur. Pada akhirnya, pemerintah daerah Cianjur memberikan respons yang baik sehingga pembangunan RSUD Pagelaran yang terletak di Selatan Kabupaten Cianjur dapat terealisasi, mengingat pada saat itu angka kematian ibu dan bayi cukup tinggi.

\section{Refleksi Teologis terhadap Gereja dan Karya Sosial}

Gereja adalah representatif Allah di dunia ini. Dengan demikian, gereja mendapat mandat untuk membawa Kabar Baik dari Allah ke dalam dunia. Dunia merupakan wilayah kerja gereja sebagai representatif Allah. Oleh karena itu, gereja tidak bisa menjauhkan dirinya terhadap persoalan yang terjadi di tengah masyarakat. Gereja diutus ke dalam dunia supaya gereja mengusahkan dan mengerjakan kebaikan bagi dunia meskipun akibat dari dosa telah merusak seluruh aspek kehidupan manusia termasuk masalah ketimpangan sosial yang sedang terjadi di masyarakat. Apakah proses bekerja dan mengusahakan adalah akibat dari dosa? Tidak. Dalam penciptaan manusia, Tuhan sekaligus memberikan mandat kepada manusia untuk "menaklukkan" bumi dengan segala isinya supaya manusia mendapatkan makanan dari padanya. Dengan kata lain, mandat kebudayaan diberikan kepada manusia sesudah manusia diciptakan dan sebelum peristiwa kejatuhan manusia ke dalam dosa. Manusia mempunyai tanggung jawab untuk mengerjakan bumi ini. Segala kemungkinan yang ada, ditemukan, diusahakan, dikelola; sehingga terwujudlah ungkapan manusia sebagai manusia, yang berbeda dengan mahluk yang lain. Di dalam ungkapan diri tersebut, manusia hidup di dalam kebudayaannya. Antara manusia dengan kebudayaannya tidak bisa dipisahkan satu dengan yang lain, oleh karena manusia yang diciptakan oleh Allah adalah manusia berkebudayaan. ${ }^{23}$ Dari pengertian ini dapat dipahami bahwa sejak awal ketika manusia diciptakan, manusia langsung diberikan mandat budaya untuk bekerja di bumi dan mandat tersebut diberikan sebelum peristiwa kejatuhan manusia ke dalam dosa. Mandat tersebut juga diteruskan kepada gereja, untuk itu gereja diutus ke dalam

${ }^{23}$ Lotnatigor Sihombing, "Tanggung Jawab Gereja dalam mewujudnyatakan Karya Kristus di Sektor Kebudayaan", jurnal Amanat Agung vol. 7 no. 2 (2011), 257-287. 
dunia sebagai representasi Allah untuk bekerja dan mengusahakan kebaikan bagi sesama.

Sebagaimana pengertian di atas, gereja diberikan mandat oleh Tuhan untuk mengusahakan kebaikan bagi sesama. Ironisnya, di kalangan kekristenan terdapat kelompok Kristen fundamentalis yang umumnya cenderung mengabaikan dunia (masyarakat) dan berupaya sekuat tenaga agar tercipta penanaman gereja (church planting) dan pertumbuhan gereja (chruch growth) sebab kemajuan dan perkembangan gereja menjadi tujuan utama. ${ }^{24}$ Bagi penulis hal demikian tidak sepenuhnya salah, namun yang perlu diperhatikan adalah apakah gereja dikatakan berhasil jika sebatas melakukan ekspansi atau membuka pos PI Gereja di berbagai kota dan daerah? Jika tujuannya hanya ekspansi berarti gereja belum sepenuhnya menjalankan fungsi Tri Tugas Panggilan gereja yaitu Koinonia (Persekutuan), Marturia (Kesaksian) dan Diakonia (Pelayanan bersentuhan kepada masyarakat) sebab kemajuan dan keberhasilan gereja juga ditentukan dari kualitas kasihnya kepada sesama.

Kisah Para Rasul 1:6-11 mencatat sikap murid-murid yang terus-menerus memandang ke langit untuk mencari ke mana Yesus Kristus pergi merupakan perbuatan dan sikap beriman yang keliru. Teguran kedua orang berpakaian putih tadi mengisyaratkan bahwa tugas para pengikut Kristus bukanlah untuk mempersiapkan anak tangga ke Surga bagi manusia melainkan membangun jembatan agar manusia dapat menyeberang ke satu kehidupan yang lebih baik. Dengan demikian, ini yang dinamakan pembaharuan paradigma pemahaman diri gereja. Iman kepada Kristus yang bangkit dan naik ke Surga haruslah membumi bukan melangit artinya mengarahkan perhatiannya kepada persoalan-persoalan kemanusiaan atau hal yang lain. ${ }^{25}$ Persoalan kemanusiaan yang dimaksudkan ialah orang-orang yang dijauhkan ataupun disingkirkan dari kekuasaan dan yang masih belum memperoleh kebutuhan mendasar dalam kehidupan. Solidaritas ataupun panggilan untuk berbuah merupakan sesuatu hal yang tidak ada pengecualian. Hematnya, gereja harus kembali kepada eksistensinya yaitu sebagai ranting-ranting Yesus yang menghasilkan buah dan menjadi tempat orang-orang besandar (Yoh 15:16). ${ }^{26}$

Selain itu, Yesus juga pernah mengajarkan kepada orang kaya untuk menjual segala yang dia miliki dan berbagi kepada orang-orang miskin agar memperoleh harta di Surga (Matius 19:21). Maksud dari perkataan Yesus ialah orang kaya jangan memiliki sikap hati yang kikir dan mementingkan dirinya sendiri tetapi hendaknya memiliki hati

\footnotetext{
${ }^{24}$ Leonard Hale, Diutus ke Dalam Dunia Menyelisik Teologi Abineno dan Kontribusinya bagi Gereja-gereja di Indonesia, 122.

${ }^{25}$ Ebenhaizer Nuban Timo, Meng-hari-ini-kan Injil di Bumi Pancasila Bergereja dengan Cita Rasa Indonesia, (Jakarta: BPK Gunung Mulia, 2017), 152-154.

26 Pintor Marihot Sitanggang, "Kepedulian Sosial Gereja”, dalam Ngapain Peduli yang lain! Gereja agen perubahan di tengah budaya masyarakat majemuk dan global- efleksi Emeritasi Pdt Nelson Siregar, 75.
} 
yang mau mengiklaskan dan berbagi kepada sesama yang membutuhkan uluran tangan sebab upah di Surga tidak sebanding dengan kekayaan yang dimiliki oleh manusia selama hidup di dunia.

Berdasarkan uraian di atas, pertanyaan yang penting untuk digumuli oleh gereja masa kini ialah apakah teologi selama ini hanyalah merupakan teologi yang melayanglayang di udara yang di bawa masuk ke gereja tetapi tidak ada kaitan dengan realitas yang ada? Padahal Yesus sendiri dalam ajaran dan pelayanan tidak membuat dikotomi antara apa yang di dalam gereja dengan apa yang terjadi di luar gereja. Ketika Yesus selesai berkhotbah kepada massa, massa kemudian menjadi lapar dan Yesus memberitahukan kepada murid-Nya untuk memberi mereka makan. Murid Yesus mengalami kebingungan mengatasi masalah tersebut. Pada akhirnya Yesus memberi makan kepada mereka dengan mukjizat 5 roti dan 2 ikan. Tetapi yang menjadi fokus utama dalam kisah ini adalah bukan pada mukjizatnya melainkan kesediaan Yesus untuk berkhotbah sekaligus kesediaannya untuk memberi mereka makan. Hal itu berarti kesediaan memberi makan merupakan kelanjutan dari khotbah Yesus. Dan inilah yang seharusnya menjadi pembaharuan pemikiran sekaligus mendorong gerejagereja di masa kini terutama bagi kaum Kristen fundamentalis untuk memiliki kesadaran dan mau terlibat dalam upaya-upaya menyelesaikan masalah-masalah ketimpangan sosial yang ada di sekitar gereja. ${ }^{27}$

\section{Kesimpulan}

GKI Cianjur merupakan salah satu dari sekian banyak gereja di Indonesia yang bisa dijadikan sebagai contoh atau model di mana GKI Cianjur terus membuka ruangruang pelayanan sosial agar banyak yang terberkati melalui kehadiran gereja tersebut. Di sisi lain, GKI Cianjur sendiri memiliki sebuah harapan yaitu di waktu mendatang gerakan aksi peduli sesama ini membuat masyarakat Cianjur bisa mandiri dan dapat menularkan aksi dan spirit yang sama kepada sesama masyarakat. Jika aksi peduli sesama ini tetap konsisten dilakukan dengan berlandaskan semangat peduli sesama atau gotong royong, maka masyarakat Cianjur bisa merasakan sejahtera lahir dan batin atau dengan kata lain kesadaran untuk memanusiakan manusia. Harapan selanjutnya ialah aksi ini bisa dijadikan sebagai salah satu model untuk kemudian diterapkan bahkan dikembangkan lebih lagi oleh gereja-gereja yang ada di Indonesia. Dampak dari aksi peduli sesama ini ialah kehadiran gereja dapat diterima dengan baik oleh masyarakat tanpa memunculkan sikap kecurigaan terhadap kehadiran gereja.

\section{Referensi}

${ }^{27}$ Arthur Aritonang, Andreas A. Yewangoe dan Oikoumene Kontribusi Pemikiran Andreas A. Yewangoe bagi Kekristenan dan Kemajemukan Agama di Indonesia, (Tesis STT Cipanas, 2020), 43. 
Aritonang, Arthur. Andreas A. Yewangoe dan Oikoumene Kontribusi Pemikiran Andreas A.

Yewangoe bagi Kekristenan dan Kemajemukan Agama di Indonesia. Tesis STT Cipanas, 2020.

Aritonang, Jan Sihar. Mereka Juga Citra Allah Hakikat dan Sejarah Diakonia Termasuk bagi

Yang Berkeadaan dan Berkebutuhan Khusus (Buruh, Migran \& Pengungsi Penyandang Disabilitas, LGBT). Jakarta: BPK Gunung Mulia, 2017.

End, Th. Van den. Harta Dalam Bejana. Jakarta: BPK Gunung Mulia, 1997.

Hale, Leonard. Diutus ke Dalam Dunia Menyelisik Teologi Abineno dan Kontribusinya bagi

Gereja-gereja di Indonesia. Jakarta: BPK Gunung Mulia, 2016.

Hale, Leonard. Jujur terhadap pietisme. Jakarta: BPK Gunung Mulia, 1993.

Harold, Rudy. "Peran "Teologi Sosial” Gereja Protestan Indonesia di Gorontalo (GPIG) dalam

Menanggapi Masalah Kemiskinan. Jurnal Jaffray, Vol. 15, No. 1, (April 2017).

Purba, Agustinus. "Gereja dan kemiskinan”, dalam Ngapain Peduli yang lain! Gereja agen

perubahan di tengah budaya masyarakat majemuk dan global - Refleksi Emeritasi

Pdt Nelson Flores Siregar, ed. Jhon Kristo Naibaho dan Morrys Syahputra Marpaung. Siborong-borong: Lembaga Bina Warga HKBP, 2017.

Sihombing, Lotnatigor. “Tanggung Jawab Gereja dalam mewujudnyatakan Karya Kristus di

Sektor Kebudayaan." jurnal Amanat Agung vol. 7 no. 2 (2011).

Sitanggang, Pintor Marihot. "Kepedulian Sosial Gereja”, dalam Ngapain Peduli yang lain! Gereja agen perubahan di tengah budaya masyarakat majemuk dan global Refleksi Emeritasi Pdt Nelson Siregar, ed. Jhon Kristo Naibaho dan Morrys Syahputra Marpaung. Siborong-borong: Lembaga Bina Warga HKBP, 2017.

Timo, Ebenhaizer Nuban. Meng-hari-ini-kan Injil di Bumi Pancasila Bergereja dengan Cita

Rasa Indonesia. Jakarta: BPK Gunung Mulia, 2017.

Yewangoe Andreas A. Theologia Crucis Di Asia Pandangan-Pandangan Orang Kristen Asia

mengenai Penderitaan dalam Kemiskinan Dan Keberagamaan di Asia. Jakarta: BPK Gunung Mulia, 1996.

\section{Makalah}

Nainggolan, Binsar. "Keterlibatan Sosial Gereja dalam Pandangan Adolf von Harnack", Makalah

Seminar, Ceramah dalam Rangka Dies Natalis STT Cipanas 2013, 7. 


\section{Daftar Laman}

Gomar gultom, peran gereja sebagai garam dan terang dunia bagi bangsa Indonesia, diakses dari https://www.youtube.com/watch?v=shs-phqh_s4, .

Setengah penduduk di Kabupaten Cianjur dinyatakan miskin, diakses dari http://jabarekspres.com/2017/setengah-pen\%c2\%adduduk-kabupaten-cianjurdinyatakan-miskin/.

Discover Your Spiritual Type: A guide to Individual and Congregational Growth Extracts from the Alban Institute Publication by Corinne Ware. 1995, dalam http://youthministry.org.nz/wp-

content/dox/groundwork_faith/personalspirituality.pdf.

Putra, Adi. "Kajian Biblika Terhadap Makna "Ta Stigmata Tou Iesou" dalam Galatia 6: 17." SUNDERMANN: Jurnal Ilmiah Teologi, Pendidikan, Sains, Humaniora Dan Kebudayaan 13.1 (2020): 1-12.

\section{Sumber: Interview}

Pdt. Robby I Chandra, D.Min., wawancara oleh penulis, 11 Juli 2018

Pdt. Hendra Setia Prasaja, S.Th., M.Si., wawancara oleh penulis 11 Juli 2018

Pdt. Dr. Einar M. Sitompul, wawancara oleh penulis 5 Juli 2018 